\title{
Safar-e Āmrīkā. Tehrān, Ketāb-e Siyāmak, 1380/2001, 383 p. [Journal d'Amérique]
}

\section{Christophe Balaÿ}

\section{Q OpenEdition \\ 1 Journals}

\section{Édition électronique}

URL : http://journals.openedition.org/abstractairanica/34665

ISSN : 1961-960X

\section{Éditeur :}

CNRS (UMR 7528 Mondes iraniens et indiens), Éditions de l'IFRI

Édition imprimée

Date de publication : 15 mai 2003

ISSN : 0240-8910

\section{Référence électronique}

Christophe Balaÿ, « Safar-e Āmrīkā. Tehrān, Ketāb-e Siyāmak, 1380/2001, 383 p. [Journal d'Amérique] », Abstracta Iranica [En ligne], Volume 24 | 2003, document 226, mis en ligne le 05 janvier 2010, consulté le 25 septembre 2020. URL : http://journals.openedition.org/abstractairanica/34665

Ce document a été généré automatiquement le 25 septembre 2020.

Tous droits réservés 


\title{
Safar-e Āmrīkā. Tehrān, Ketāb-e Siyāmak, 1380/2001, 383 p. [Journal d'Amérique]
}

\author{
Christophe Balaÿ
}

1 Journal de voyage de Jalāl Āl-e Aḥmad aux États-Unis d'Amérique. Le voyage était inédit. On doit cette édition à Moștafāa Zamānī-Niyā, sous la direction de Šams Āl-e Aḥmad. J. Āl-e Aḥmad a effectué ce voyage et rédigé cette relation pendant l'été 1344/1965. Quiconque un tant soit peu connaisseur de la personnalité de l'écrivain et du rôle joué par l'intellectuel dans le contexte politique des années 60 ainsi que de l'impact de son œuvre dans la littérature persane contemporaine, saisira l'importance de la publication de cette œuvre inédite, d'une certaine ampleur par rapport aux autres journaux de voyage d'Āl-e Ahmad. La virulence du propos - qui en interdit la publication - et la renvoie trente-cinq ans plus tard, trahit l'état d'inquiétude et de fureur dans lequel se trouve Āl-e Ahmad pendant les dernières années de son existence (il mourra quatre ans plus tard). L'écrivain se rend aux USA, à l'université d'Harvard, à l'invitation des autorités américaines dans le cadre d'une conférence estivale annuelle des écrivains étrangers et américains, tenue pour établir un contact entre divers intellectuels et l'Amérique. La toile de fond politique est bien visible et le contexte historique international (la guerre du Vietnam, la guerre froide...) se double pour Āl-e Ahmad du contexte iranien contraignant pour les intellectuels. Le régime Pahlavī laisse peu de répit à son intelligentsia et c'est en apprenant la nouvelle de l'arrestation de Halīl Malekī et de quelques-uns de ses amis qu'Āl-e Ahmad, hésitant tout d'abord, se décide à rentrer en Iran. Ce voyage en Amérique prend d'autant plus de poids et d'intérêt quand on sait qu'il est contemporain de la genèse de "Ǵarbzadegī », le célèbre essai de l'écrivain qui ne parut dans son intégralité qu'après la révolution de 1978 et qui contient bien des traits, bien des analyses qui nourriront la pensée révolutionnaire iranienne. Le journal de voyage est suivi d'un extrait du Kārnāme-ye se sāle (bilan de trois années), relatif au « kārnāme-ye do māhe » de Harvard. Puis un très riche index des noms. CEuvre capitale, donc, pour contribuer à l'interprétation de l'ensemble des 
écrits d'Āl-e Ahmmad, comme de l'histoire des idées politiques dans l'Iran prérévolutionnaire.

INDEX

Thèmes: 11.1.2. Littérature persane moderne

\section{AUTEURS}

\section{CHRISTOPHE BALAŸ}

IFRI - INaLCO - Téhéran - Paris 